\title{
PENGGUNAAN MULTIMEDIA DALAM MENINGKATKAN MOTIVASI BELAJAR SISWA PADA MATA PELAJARAN PENDIDIKAN AGAMA ISLAM DI KELAS X SMA NEGERI 5 BURU KECAMATAN LILIALY KABUPATEN BURU
}

\author{
Tiarni Soamole ${ }^{1}$ Samad Umarella ${ }^{2}$ Saddam Husein ${ }^{3}$ \\ Program Studi Pendidikan Agama Islam, Fakultas IImu Tarbiyah dan Keguruan \\ Institut Agama Islam Negeri Ambon ${ }^{1}$ \\ Email: tiarni@iainambon.ac.id
}

\begin{abstract}
This study aims to find out how the use of multimedia in improving students' learning motivation in Islamic Religious Education subjects in the Classroom X SMA Negeri 5 Buru as well as supporting factors and inhibition of the use of multimedia. This research was conducted in SMA Negeri 5 Buru District Lilialy Kabupaten Buru, from September 1, 2020 to October 1, 2020. This research is a qualitative descriptive research with data collection techniques in the form of observations, interviews and documentation. The collected data is then analyzed qualitatively including: data collection, data reduction, data display and verification and affirmation of conclusions. The results showed that the use of multimedia can increase students' learning motivation in Islamic Religious Education subjects in the classroom X SMA Negeri 5 Buru, where students appear to focus on following the learning process, recording the subject matter, and are happy with the learning using multimedia, students easily explain or answer the teacher's questions PAl boldly and actively in the learning process. Supporting factors and inhibition factors of multimedia use in increasing students' learning motivation in Islamic Religious Education subjects in the Classroom X SMA Negeri 5 Buru among others, for supporting factors, namely the availability of leptop and computer, infokus, electricity, clean school walls, clean classrooms, and the ability of PAl teachers who are very good in integrating concepts with multimedia in the learning process as well as the availability of special classrooms designed for learning activities using multimedia infokus. As for the inhibition factor is infokus available only one, so it will be constrained when used by other teachers, then electricity is often out and internet access is often sluggish.
\end{abstract}

Keywords: Multimedia, student learning motivation, Islamic Religious Education

\begin{abstract}
Abstrak: Penelitian ini bertujuan untuk mengetahui bagaimana penggunaan multimedia dalam meningkatkan motivasi belajar siswa pada mata pelajaran Pendidikan Agama Islam di Kelas X SMA Negeri 5 Buru serta faktor pendukung dan penghambat penggunaan multimedia tersebut..Penelitian ini dilaksanakan di SMA Negeri 5 Buru Kecamatan Lilialy Kabupaten Buru, mulai dari tanggal 1 September 2020 sampai dengan 1 Oktober 2020.. Penelitian ini merupakan penelitian deskriptif kualitatif dengan teknik pengumpulan data berupa observasi, wawancara dan dokumentasi. Data yang terkumpul kemudian dianalisis secara kualitatif meliputi: pengumpulan data, reduksi data, display data dan verifikasi dan penegasan kesimpulan. Hasil penelitian menunjukkan bahwa penggunaan multimedia dapat meningkatkan motivasi belajar siswa pada mata pelajaran Pendidikan Agama Islam di kelas X SMA Negeri 5 Buru, dimana siswa terlihat mereka fokus mengikuti proses pembelajaran, mencatat materi pelajaran, dan senang dengan pembelajaran menggunakan multimedia, siswa dengan mudah menjelaskan atau menjawab pertanyaan guru PAI dengan berani dan aktif dalam proses pembelajaran. Faktor pendukung dan faktor penghambat penggunaan multimedia dalam meningkatkan motivasi belajar siswa pada mata pelajaran Pendidikan Agama Islam di Kelas X SMA Negeri 5 Buru antara lain untuk faktor pendukung yakni tersedianya leptop dan komputer, infokus, listrik, dinding sekolah yang bersih, ruang kelas yang bersih, dan kemampuan guru PAI yang sangat baik dalam mengintegrasikan konsep dengan multimedia dalam
\end{abstract}


proses pembelajaran serta tersedianya ruang kelas khusus yang didesain untuk kegiatan pembelajaran menggunakan multimedia infokus. Sementara untuk faktor penghambatnya adalah infokus yang tersedia hanya satu, sehingga akan terkendala apabila digunakan oleh guru yang lain, kemudian listrik sering padam dan akses internet yang sering lamban.

Kata kunci: Multimedia, motivasi belajar siswa, Pendidikan Agama Islam

\section{PENDAHULUAN}

Pendidikan adalah usaha sadar untuk menyiapkan siswa melalui kegiatan bimbingan, pengajaran, dan/atau latihan bagi perencanaan di masa yang akan datang (Oemar Hamalik, 2012). Dalam arti lain pendidikan merupakan pendewasaan siswa yang dilakukan oleh pengajar agar dapat mengembangkan bakat, potensi dan keterampilan yang dimiliki siswa dalam menjalani kehidupan. Oleh karena itu, sudah seharusnya perlu adanya desain pembelajaran dalam pendidikan guna untuk meningkatkan prestasi, motivasi belajar, bakat dan keterampilan yang dimiliki siswa.

Pembelajaran merupakan proses belajar yang dilakukan secara sadar dalam upaya mencerdaskan siswa. Di dalamnya terjadi interaksi antara berbagai komponen yaitu guru, siswa dan materi pelajaran atau sumber belajar. Interaksi antara ketiga komponen ini melibatkan sarana dan prasarana seperti metode, media dan penataan lingkungan tempat belajar sehingga tercipta suatu proses pembelajaran yang memungkinkan tercapainya tujuan yang ingin dicapai (Heri Gunawan, 2012).

Perkembangan ilmu pengetahuan akhir-akhir ini begitu pesat, antara lain munculnya berbagai inovasi-inovasi baru yang berbasis multimedia teknologi. Perkembangan tersebut juga berdampak pada sistem pendidikan di Indonesia yang mulai beralih dari pembelajaran yang tradisional berubah menjadi pembelajaran berbasis multimedia teknologi (Ahmad Fatkhul Huda, 2014) Multimedia adalah penggunaan komputer untuk menyajikan dan menggabungkan teks, suara, gambar, animasi dan video dengan alat bantu (tool) dan koneksi (link) sehingga pengguna dapat melakukan navigasi, berinteraksi, berkarya dan berkomunikasi. 
Multimedia sering digunakan dalam dunia hiburan. Selain dari dunia hiburan, multimedia juga diadopsi oleh dunia game (Daryanto, 2003).

Media pembelajaran berbasis multimedia menjadi alternatif sebagai media anjuran karena berbagai alasan yaitu : pelajaran akan lebih menarik perhatian siswa, guru dapat mengkombinasikan audio dan visual secara bersamaan, dapat dikombinasikan dengan strategi lain, siswa lebih aktif dan memotivasi belajar siswa. Dapat dipahami bahwa multimedia pembelajaran menyasar pada karakteristik siswa yang memiliki variasi gaya belajar yang berbeda-beda. Hal itu tentunya akan berdampak pada motivasi belajar siswa meningkat.

Motivasi diartikan sebagai dorongan seseorang melakukan sesuatu. Motivasi seseorang dapat dipengaruhi oleh faktor dari dalam (intrinsik) dan faktor dari luar (ekstrinsik). Siswa yang termotivasi dalam belajarnya dapat dilihat dari karakteristik tingkah laku yang menyangkut minat, perhatian, konsentrasi dan ketekunan. Motivasi menjadi salah satu faktor yang turut menentukan hasil belajar.

Berdasarkan hasil observasi awal, proses pembelajaran pada mata pelajaran Pendidikan Agama Islam di SMA Negeri 5, diketahui bahwa guru PAI telah menggunakan multimedia dalam pembelajaran di kelas, hal ini dilakukan sebagai bagian dari tuntutan penerapan kurikulum 2013 (Observasi, 2020). Hasil wawancara awal dengan Bapak Rahman Hasanudin, guru mata pelajaran Pendidikan Agama Islam di kelas X SMA Negeri 5 Buru, menunjukkan bahwa selama ini ia telah menggunakan multimedia dalam proses pembelajaran PAI di setiap kelas, termasuk kelas X (Wawancara. Rahman Hasanudin, 2020). Multimedia yang digunakan pada mata pelajaran PAI yakni media power point (slide) yang diproyeksikan melalui infokus (LCD).

Hasil observasi awal juga mengungkap bahwa motivasi belajar siswa pada mata pelajaran PAI di kelas $X$ belum begitu terlihat. Sebagian siswa terlihat begitu bersemangat dalam pembelajaran mata pelajaran PAI menggunakan multimedia (power point/slide), yakni dengan menulis 
materi pelajaran, aktif bertanya dan menjawab maupun memberi tanggapan. Namun sebagian besar siswa lainnya masih terlihat pasif dalam proses mengajar mata pelajaran PAI menggunakan multimedia, antara lain tidak mencatat materi pelajaran, tidak mau bertanya meski telah dipersilahkan oleh guru, dan tidak fokus mengikuti pelajaran di dalam kelas. Demikian demikian, hingga kini belum diketahui secara jelas apakah penggunaan multimedia tersebut berdampak baik terhadap meningkatnya motivasi belajar siswa pada mata pelajaran PAI di kelas $\mathrm{X}$ SMA Negeri 5 Buru.

Berdasarkan penjelasan-penjelasan di atas, maka penulis tertarik untuk melakukan sebuah penelitian dengan judul "Penggunaan Multimedia dalam Meningkatkan Motivasi Belajar Siswa pada Mata Pelajaran Pendidikan Agama Islam di Kelas X SMA Negeri 5 Buru Kecamatan Lilialy Kabupaten Buru".

Penelitian ini bertujuan untuk mengetahui bagaimana penggunaan multimedia dalam meningkatkan motivasi belajar siswa pada mata pelajaran Pendidikan Agama Islam di Kelas X SMA Negeri 5 Buru serta faktor pendukung dan penghambat penggunaan multimedia tersebut.

\section{METODE}

Jenis penelitian yang dilakukan adalah penelitian ex post facto, yakni peneliti langsung berada di lokasi penelitian untuk melakukan interview langsung dengan informan untuk memperoleh informasi tentang masalah yang diteliti. Sementara pendekatan yang digunakan adalah pendekatan deskriptif kualitatif, yaitu berupa kata-kata tertulis atau lisan dari orang-orang dan perilaku yang dapat diamati, menggambarkan suatu fakta, gejala atau fenomena yang ditemukan di lapangan atau yang dipelajari (Margono, 2009). Prosedur pengumpulan data yang digunakan dalam penelitian ini adalah pengamatan lapangan (observasi), wawancara (interview) dan dokumentasi. Analisis data dilakukan secara kualitatif dengan mengacu pada model Milles dan Huberman meliputi Reduksi Data 
(Data Reducation), Penyajian Data (Data Display) dan Penarikan Kesimpulan (Verification).

\section{HASIL DAN PEMBAHASAN}

\section{A. Penggunaan Multimedia dalam Meningkatkan Motivasi Belajar Siswa pada Mata Pelajaran PAI di Kelas X SMA Negeri 5 Buru}

Berdasarkan penelitian yang dilakukan mengenai penggunaan multimedia dalam meningkatkan motivasi belajar siswa pada mata pelajaran PAI di kelas X SMA Negeri 5 Buru dapat disajikan hasil pengamatan atau observasi peneliti terhadap kegiatan guru PAI dalam melakukan pembelajaran sebagai berikut:

Tabel 4.1. Hasil Observasi Penggunaan Multimedia pada Mata Pelajaran PAI di Kelas X SMA Negeri 5 Buru

\begin{tabular}{|c|c|c|c|}
\hline \multirow{2}{*}{ No. } & \multirow{2}{*}{ Komponen Observasi } & \multicolumn{2}{|c|}{ Hasil Observasi } \\
\hline & & $\mathrm{Ya}$ & Tidak \\
\hline 1. & $\begin{array}{lll}\text { Guru PAI } & \text { melakukan } & \text { kegiatan } \\
\text { apersepsi } & \text { sebagai } & \text { pengantar } \\
\text { pembelajaran. } & & \end{array}$ & $\sqrt{ }$ & \\
\hline 2. & $\begin{array}{l}\text { Guru PAl menyampaikan judul } \\
\text { pembelajaran. }\end{array}$ & $\sqrt{ }$ & \\
\hline 3. & $\begin{array}{lcr}\text { Guru PAI } & \text { menyampaikan } & \text { tujuan } \\
\text { pembelajaran } & \text { pada } & \text { setiap } \\
\text { pembelajaran } & \text { menggunakan } \\
\text { multimedia } & & \end{array}$ & $\sqrt{ }$ & \\
\hline 4. & $\begin{array}{l}\text { Guru PAl menggunakan dan } \\
\text { menerangkan materi dengan } \\
\text { menggunakan multimedia yang menarik }\end{array}$ & $\sqrt{ }$ & \\
\hline 5. & $\begin{array}{l}\text { Guru PAl menyuruh siswa mengamati } \\
\text { tentang slide (gambar) yang } \\
\text { ditampilkan }\end{array}$ & $\sqrt{ }$ & \\
\hline 6. & Guru PAI memberikan pertanyaan dan & $\sqrt{ }$ & \\
\hline
\end{tabular}




\begin{tabular}{|c|l|c|c|}
\hline & kesempatan bertanya kepada siswa & & \\
\hline 7. & $\begin{array}{l}\text { Guru PAl memberikan motivasi kepada } \\
\text { siswa dalam pembelajaran PAI }\end{array}$ & $\sqrt{ }$ & \\
\hline 8. & $\begin{array}{l}\text { Guru PAI mengevaluasi siswa dalam } \\
\text { pembelajaran. }\end{array}$ & $\sqrt{ }$ & \\
\hline 9. & $\begin{array}{l}\text { Guru PAI mengarahkan siswa } \\
\text { mempraktekan setiap materi yang } \\
\text { diajarkan menggunakan multimedia }\end{array}$ & $\sqrt{ }$ & \\
\hline
\end{tabular}

Sumber; Hasil Observasi, 2020.

Berdasarkan hasil observasi terhadap penggunaan multimedia pada mata pelajaran PAI di kelas X SMA Negeri 5 Buru, dapat diketahui bahwa penggunaan multimedia oleh guru PAl sudah sesuai dengan Rencana Pelaksanaan Pembelajaran (RPP) yang telah disusun sebelumnya. Pada pembelajaran PAI guru menggunakan multimedia dalam bentuk power point yang ditampilkan menggunakan infokus dan secara keseluruhan media infokus yang digunakan oleh guru dalam pembelajaran PAI sudah jelas dan baik. Power point yang ditampilkan berupa gambar, animasi dan video yang disertai dengan deskripsi.

Sementara hasil observasi terhadap aktivitas guru, dapat dijelaskan bahwa guru PAI melakukan kegiatan apersepsi sebagai pengantar pembelajaran dengan multimedia (power point), menyampaikan judul pembelajaran, menyampaikan tujuan pembelajaran, menerangkan materi pelajaran sesuai dengan poin-poin pada multimedia power point yang ditampilkan, menyuruh siswa mengamati tentang slide yang ditampilkan, ia juga memberikan pertanyaan dan kesempatan bertanya kepada siswa. Selain itu, guru PAI memberikan motivasi kepada siswa dalam pembelajaran PAI. Pada bagian akhir, guru PAI mengevaluasi siswa dalam pembelajaran dengan media power point dan mengarahkan siswa mempraktekan materi yang sedang diajarkan dalam kehidupan sehari-hari (Observasi, 2020). 
Kemudian untuk hasil pengamatan terhadap aktivitas siswa dalam pembelajaran PAI menggunakan multimedia infokus, dapat dikemukakan bahwa siswa sangat baik dalam mendengarkan dan memperhatikan penjelasan yang disampaikan oleh guru, siswa aktif saat pembelajaran berlangsung, siswa juga mencatat materi pembelajaran, siswa mengikuti arahan/perintah dari guru dengan sangat baik, bekerja sama dalam proses pembelajaran dengan baik, serta siswa sangat baik juga dalam hal menghargai siswa yang lain pada saat menyampaikan pendapat.

Berdasarkan hasil wawancara dengan informan dalam penelitian ini, dapat diketahui bahwa penggunaan multimedia dapat meningkatkan motivasi belajar siswa pada mata pelajaran Pendidikan Agama Islam di kelas X SMA Negeri 5 Buru, di mana siswa mereka terlihat:

1. Siswa fokus dalam mengikuti materi pembelajaran

2. Siswa lebih mudah mencatat materi pembelajaran

3. Siswa merasa senang dengan pembelajaran menggunakan multimedia

4. Siswa mudah menjelaskan dan menjawab pertanyaan guru dengan baik.

Berikut ini adalah penjelasan mengenai 4 (empat) point tersebut:

\section{Siswa fokus dalam mengikuti materi pembelajaran}

Berdasarkan hasil observasi yang dilakukan untuk mengetahui penggunaan multimedia pada mata pelajaran PAI di Kelas X SMA Negeri 5 Buru sebagaimana yang ditampilkan pada Tabel 4.2, dapat dijelaskan bahwa siswa kelas X SMA Negeri 5 Buru fokus dalam mengikuti materi pembelajaran. Hal ini karena guru PAI menyuruh siswa mengamati tentang slide (gambar) yang ditampilkan, guru PAI memberikan pertanyaan dan kesempatan bertanya kepada siswa, memberikan motivasi kepada siswa dalam pembelajaran PAI serta mengarahkan siswa mempraktekan setiap materi yang diajarkan menggunakan multimedia. Guru PAI di SMA Negeri 5 Buru sangat paham bahwa untuk mencapai tujuan pembelajaran, maka siswa perlu 
diarahkan atau diinstruksikan untuk fokus pada pembelajaran yang sedang berlangsung.

Selanjuntnya berdasarkan hasil wawancara dengan guru mata pelajaran PAI dan siswa kelas $X$ di SMA Negeri 5 Buru, dapat dijelaskan bahwa penggunaan media infokus mampu membuat siswa fokus dalam mengikuti materi pembelajaran Pendididikan Agama Islam. Hal ini sebagaimana pernyataan guru mata pelajaran pendidikan Agama Islam dan siswa kelas X di SMA Negeri 5 Buru sebagai berikut:

"Mengajar menggunakan media menurut saya lebih baik, karena siswa selama saya menggunakan media mereka sangat memperhatikan pelajaran yang saya ajarkan. Dan ketika menggunakan media ini nilai-nilai siswa sangat bagus, karena mereka paham dan mampu menyelesaiakan soal yang diberikan dengan baik pula (Wawancara. Rahman Hasanudin, 2020).

Pernyataan guru PAI ini dibenarkan oleh Irwandi Buton, siswa kelas $\mathrm{X}$ sebagai berikut:

"Saya sangat senang belajar dengan menggunakan media infokus, karena saya dapat melihat langsung apa yang diajarkan, kalau tidak pakai gambar itu sulit untuk dimengerti, walaupun guru sudah mengulang. Jadi menurut saya sangat bagus karena saya lebih paham kalau menggunakan infoku" (Wawancara. Irwandi Buton, 2020).

Hasil wawancara tersebut sejalan dengan Hamalik dalam Azhar Arsyad, ia mengemukakan bahwa pemakaian media pembelajaran infokus dalam proses belajar mengajar dapat membangkitkan keinginan dan minat baru, membangkitkan motivasi dan rangsangan kegiatan belajar, dan bahkan membawa pengaruh psikologis terhadap siswa (Azhar Arsyad, 2006). 
Ketertarikan siswa dalam mengikuti kegiatan pembelajaran adalah ketika siswa diminta untuk memperhatikan video, gambar dan animasi. Hal yang belum dilakukan sebelumnya ini memberikan suasana pembelajaran yang baru sehingga setiap tugas yang diberikan oleh guru selalu dikerjakan oleh siswa. Ketertarikan siswa menjadikan siswa berkonsentrasi dalam menerima materi dan perhatiannya diberikan khusus untuk pembelajaran. Hal ini menyebabkan suasana pembelajaran menjadi kondusif dan siswa sudah tidak ramai lagi di dalam kelas.

\section{Siswa lebih mudah mencatat materi pembelajaran}

Hasil wawancara dengan informan dalam penelitian ini menunjukkan bahwa penggunaan media infokus lebih baik bagi siswa kelas X SMA Negeri 5 Buru, antara lain mereka memperhatikan pelajaran yang diajarkan dan menulis materi pelajaran yang penting. Berikut kutipan hasil wawancara mengenai hal tersebut:

"Ketika proses pembelajaran menggunakan media infokus ini, saya melihat siswa cukup aktif menulis materi atau informasi-informasi penting yang diperoleh dalam pembelajaran. Hal ini mungkin karena penggunaan media infokus tampilan tulisan itu cukup jelas, sehingga siswa juga mudah untuk mencatat" (Wawancara. Rahman Hasanudin, 2020).

Penjelasan di atas menunjukkan bahwa dengan menggunakan media infokus ini, waktu yang digunakan untuk mengajar tidak terbuang sia-sia hanya untuk menulis di papan tulis, dan membuat catatan. Selain itu kualitas visual akan lebih nyaman dengan materi yang dapat terlihat dengan jelas di banding dengan menulis di papan tulis. Hal inilah yang dapat membuat waktu belajar menjadi efektif, dan suasana belajar menjadi efisien, karena guru aktif dan kreatif dalam pembelajaran dan siswa juga aktif mencatat materi pelajaran. 
Selain meningkatkan kemampuan kreativitas guru, penggunaan multimedia dalam pembelajaran PAI memudahkan guru dalam menyajikan materi. Hal ini sesuai dengan penelitian yang dilakukan oleh Renate Motschnig-Pitrik and Andreas Holzinger (2005) dalam penelitiannya yang berjudul student-centered teaching meets new media: concept and case study. Dalam penelitian ini membahas guru dapat mengoptimalkan waktu belajar dengan menggunakan multimedia. Guru tidak perlu menuliskan materi di papan white board dan langsung menampilkan di depan kelas. Hal ini akan lebih menghemat waktu dan waktu belajar lebih optimal.

\section{Siswa merasa senang dengan pembelajaran menggunakan multimedia}

Menurut Bapak Rahman Hasanudin bahwa proses belajar menggunakan media infokus membuat siswa senang sehingga proses belajar mengajar terdapat respon dari siswa. Hal ini sebagaimana pernyataannya sebagai berikut:

"Dalam proses belajar mengajar siswa itu terlihat senang sehingga pembelajaran dalam kelas adanya respon atau timbal balik antara guru dan siswa ataupun dalam memberikan pertanyaan siswa cepat menjawab atau menanggapi pertanyaan yang telah diberikan. Untuk proses pembelajaran di dalam kelas selama saya mengajar dengan memakai video atau gambar-gambar yang saya dapat siswa itu cepat memahami dan aktif dalam proses pembelajaran itu mulai hingga berakhir. Jadi bagi saya untuk kedua media tersebut itu siswa termotivasi dalam belajar" (Wawancara. Rahman Hasanudin, 2020).

Siswa yang memiliki minat belajar dan sikap positif terhadap pelajaran akan merasa senang mempelajari mata pelajaran tertentu, sehingga dapat mencapai hasil pembelajaran yang optimal. Walaupun para pendidik sadar akan hal ini, namun belum banyak tindakan yang 
dilakukan pendidik secara sistematik untuk meningkatkan minat siswa. Oleh karena itu untuk mencapai hasil belajar yang optimal, dalam merancang program pembelajaran dan kegiatan pembelajaran bagi siswa, pendidik harus memperhatikan karakteristik afektif siswa.

Siswa merasa senang dengan pembelajaran menggunakan multimedia. Hal ini dapat dilihat dari indikator-indikator pengamatan aspek afektif siswa selama proses pembelajaran berlangsung menggunakan multimedia infokus, antara lain keaktifan siswa yang sangat baik, fokus siswa sangat baik dalam mengikuti pembelajaran dan para siswa juga saling menghargai ketika temannya menyampaikan pendapat dalam kegiatan pembelajaran. Hal ini sejalan dengan pendapat Trianto dalam Rusmiati $d k k$ yang mengemukakan bahwa salah satu kelebihan penggunaan multimedia dalam pembelajaran yakni siswa akan memperoleh kepercayaan akan (kemampuan) diri sendiri (Ida Rusmiyati, 2014).

\section{Siswa mudah menjelaskan dan menjawab pertanyaan guru dengan baik}

Hasil pengamatan peneliti di ruang kelas ketika guru memberikan pembelajaran menggunakan multimedia, terlihat bahwa siswa sangat aktif dalam mengikuti proses belajar mengajar. Siswa berani bertanya, memberikan tanggapan, menjawab pertanyaan guru maupun pertanyaan dari teman-temannya.

Menurut kepala sekolah SMA Negeri 5 Buru, penggunaan multimedia (infokus) dalam proses pembelajaran sangat mempermudah siswa berbicara, baik itu menyampaikan pertanyaan maupun menanggapi pernyataan guru. Berikut pernyataannya:

"Bagi saya penggunaan media infokus dalam semua mata pelajaran dan terutama untuk mata pelajaran PAI sangat mempermudah siswa untuk bertanya, menjawab pertanyaan guru atau teman, jadi mereka semakin aktif di ruang kelas. Guru jelaskan materi mereka juga cepat paham. Ini artinya 
bahwa belajar menggunakan media seperti infokus membuat siswa cepat paham sehingga bisa berinteraksi langsung dalam proses pembelajaran" (Wawancara. Ny. Ina Hi. Ismail, 2020).

Pendapat salah satu siswa kelas X, yakni Kasmiatun Umasugi, yakni sebagai berikut:

"Kalau belajar menggunakan media infokus membuat kami di ruangan semakin berani bertanya, kami semua sudah mulai berani bertanya, berani menjawab pertanyaan guru" (Wawancara. Kasmiatun Umasugi, 2020).

Pernyataan Kasmiatun Umasugi juga dibenarkan Irwandi Buton sebagai berikut:

"Saya sekarang sudah mulai berani bertanya di kelas kalau saya tidak mengerti, saya tanya saja kepada ibu guru. Saya sudah tidak takut untuk bertanya" (Wawancara. Irwandi Buton, 2020).

Berdasarkan hasil wawancara tersebut, dapat dijelaskan bahwa penggunaan media infokus dapat meningkatkan motivasi belajar siswa kelas X pada pembelajaran PAI di SMA Negeri 5 Buru, karena dari aspek kognitif siswa kelas $X$ semakin mudah memahami materi pelajaran dan mampu menyelesaikan soal dengan baik ketika dalam proses pembelajaran menggunakan media.

Penggunaan multimedia dalam pembelajaran memiliki hubungan yang penting dalam meningkatkan motivasi belajar siswa. Multimedia adalah media yang menggabungkan dua unsur atau lebih yang terdiri dari teks, grafis, gambar, audio, video, dan animasi secara terintegrasi. multimedia terbagi menjadi dua kategori yaitu : multimedia linier dan multimedia interaktif. Multimedia memudahkan pembelajaran yang berpusatkan pada siswa karena siswa diberi kebebasan memilih bahan pembelajaran sendiri dan belajar pada kadar yang sesuai dengan diri sendiri. Multimedia dapat digunakan untuk membantu pembelajar 
membentuk "model mental" yang akan memudahkannya memahami suatu konsep.

Siswa yang bermotivasi tinggi dalam belajar memungkinkan akan memperoleh hasil belajar yang tinggi pula, artinya semakin tinggi motivasinya, semakin intensitas usaha dan upaya yang dilakukan, maka semakin tinggi hasil belajar yang diperolehnya. Siswa melakukan berbagai upaya atau usaha untuk meningkatkan keberhasilan dalam belajar sehingga mencapai keberhasilan yang cukup memuaskan sebagaimana yang diharapkan. Di samping itu motivasi juga menopang upaya-upaya dan menjaga agar proses belajar siswa tetap jalan. Hal ini menjadikan siswa gigih dalam belajar.

Pernyataan Weiner dalam Setyowati, bahwa siswa yang memiliki motivasi untuk berhasil akan bekerja lebih keras daripada orang yang memiliki motivasi untuk tidak gagal. Dengan demikian siswa yang memiliki motivasi untuk berhasil harus diberi pekerjaan yang menantang dan sebaliknya jika siswa yang memiliki motivasi untuk tidak gagal sebaiknya diberi pekerjaan yang kira-kira dapat dikerjakan dengan hasil yang baik. Apabila motif atau motivasi belajar timbul setiap kali belajar, besar kemungkinan hasil belajarnya meningkat. Banyak bakat siswa tidak berkembang karena tidak memiliki motif yang sesuai dengan bakatnya itu. Apabila siswa itu memperoleh motif sesuai dengan bakat yang dimilikinya itu, maka lepaslah tenaga yang luar biasa sehingga tercapai hasil-hasil belajar yang semula tidak terduga (Setyowati, 2007).

\section{B. Faktor Pendukung Dan Faktor Penghambat Penggunaan} Multimedia dalam Meningkatkan Motivasi Belajar Siswa pada Mata Pelajaran PAI di Kelas X SMA Negeri 5 Buru

Berdasarkan hasil penelitian ini, maka faktor pendukung dan faktor penghambat penggunaan multimedia dalam meningkatkan motivasi belajar siswa pada mata pelajaran Pendidikan Agama Islam di Kelas X SMA Negeri 5 Buru dapat dipaparkan sebagai berikut: 
Untuk faktor pendukung penggunaan multimedia dalam meningkatkan motivasi belajar siswa pada mata pelajaran Pendidikan Agama Islam di Kelas X SMA Negeri 5 Buru antara lain adalah:

1. Tersedia Sarana dan Prasarana

Menurut Bapak Rahman Hasanudin, bahwa faktor pendukung berupa sarana dan prasarana dalam menggunakan media infokus di SMA Negeri 5 Buru antara lain adalah tersedianya leptop dan komputer serta akses internet, tersedianya infokus dalam kondisi baik, tersedia listrik, dan dinding sekolah yang bersih serta ruang kelas yang bersih. Sedangkan menurut Ny. Ina Hi. Ismail, selaku Kepala Sekolah SMA Negeri 5 Buru, bahwa salah satu faktor yang baik dalam mendukung proses pembelajaran menggunakan media infokus adalah tersedianya ruang kelas khusus yang didesain untuk kegiatan pembelajaran menggunakan multimedia infokus.

Berdasarkan hasil wawancara dalam penelitian ini mengenai sarana dan prasarana pendukung penggunaan multimedia dalam pembelajaran PAI, antara lain adalah tersedianya leptop dan komputer serta akses internet, tersedianya infokus dalam kondisi baik, tersedia listrik, dinding sekolah yang bersih, ruang kelas yang bersih dan tersedianya ruang kelas khusus yang didesain untuk kegiatan pembelajaran menggunakan multimedia infokus.

2. Kemampuan guru PAI yang sangat baik dalam mengintegrasikan konsep dengan multimedia dalam proses pembelajaran.

Faktor pendukung lainnya dalam penggunaan media infokus dalam pembelajaran PAI untuk meningkatkan motivasi belajar siswa yakni kemampuan guru PAI yang sangat baik dalam mengintegrasikan konsep dengan multimedia dalam proses pembelajaran. Menurut kepala sekolah SMA Negeri 5 Buru, bahwa guru PAI di sekolah yang ia pimpin ini memiliki kemampuan yang sangat baik dalam menggunakan media infokus. Menurutnya, guru PAl memahami penggunaan multimedia (infokus) dalam proses pembelajaran, sehingga sangat 
mempermudah siswa berbicara ketika pembelajaran berlangsung, baik itu menyampaikan pertanyaan maupun menanggapi pernyataan guru.

Hasil penelitian ini memberi gambaran bahwa guru PAI memiliki kemampuan menggunakan alat penghubung dalam proses interaksi belajar mengajar untuk meningkatkan efektifitas hasil belajar, guru mamou menyesuaikan media pembelajatan dengan orientasi dan tujuan pembelajaran. Ada beberapa alasan berkenaan dengan pemilihan teknologi pendidikan sebagai media pembelajaran. Diantaranya pelajaran akan lebih menarik perhatian siswa, bahan pelajaran akan lebih mudah dipahami oleh siswa, metode pembelajaran akan lebih bervariasi, dan siswa akan lebih banyak melakukan kegiatan belajar. Bahkan penggunaan media akan mempertinggi kualitas proses dan hasil pembelajaran. Multimedia merupakan salah satu teknologi pendidikan yang dapat menghadirkan visualisasi dari materi pelajaran.

Sementara untuk faktor penghambat penggunaan multimedia dalam meningkatkan motivasi belajar siswa pada mata pelajaran Pendidikan Agama Islam di Kelas X SMA Negeri 5 Buru antara lain:

1. Infokus yang tersedia hanya satu, sehingga akan terkendala apabila digunakan oleh guru yang lain;

2. Listrik sering padam

3. Akses internet yang sering lamban.

Sebagai upaya mengatasi adanya kendala dalam proses pembelajaran menggunakan media infokus, maka guru PAl akan menggunakan media pembelajaran lainnya yang dapat membangkitkan motivasi dan semangat belajar siswa di kelas,m seperti dadu. Selain itu, ia akan memberikan penguatan kepada siswa dalam proses pembelajaran, seperti pujian maupun hadiah.

Berdasarkan hasil wawancara dengan guru PAI tersebut, dapat dipahami bahwa apabila ada kendala ketika proses pembelajaran dilakukan dengan menggunakan media infokus, maka guru harus memiliki 
kemampuan dalam pengelolaan kelas yang baik dan kemampuan memberikan penguatan kepada siswa. Guru dituntut mampu memahami karakter siswa, sehingga tujuan pembelajaran mudah dicapai.

\section{KESIMPULAN}

1. Penggunaan multimedia dapat meningkatkan motivasi belajar siswa pada mata pelajaran Pendidikan Agama Islam di kelas X SMA Negeri 5 Buru, di mana siswa mereka terlihat:

a. Siswa fokus dalam mengikuti materi pembelajaran

b. Siswa lebih mudah mencatat materi pembelajaran

c. Siswa merasa senang dengan pembelajaran menggunakan multimedia

d. Siswa mudah menjelaskan dan menjawab pertanyaan guru dengan baik.

2. Faktor pendukung penggunaan multimedia dalam meningkatkan motivasi belajar siswa pada mata pelajaran Pendidikan Agama Islam di Kelas X SMA Negeri 5 Buru antara lain untuk faktor pendukung yakni tersedianya leptop dan komputer, infokus, listrik, dinding sekolah yang bersih, ruang kelas yang bersih, dan kemampuan guru PAI yang sangat baik dalam mengintegrasikan konsep dengan multimedia dalam proses pembelajaran serta tersedianya ruang kelas khusus yang didesain untuk kegiatan pembelajaran menggunakan multimedia infokus. Sementara untuk faktor penghambatnya adalah infokus yang tersedia hanya satu, sehingga akan terkendala apabila digunakan oleh guru yang lain, kemudian listrik sering padam dan akses internet yang sering lamban.

\section{UCAPAN TERIMA KASIH}

Penulis menyampaikan terima kasih dan penghormatan yang tulus kepada kedua orang tua yang telah melahirkan dan membesarkan serta dengan segala kerendahan hati memberikan dukungan, nasehat, doa dan pengorbanan dan perjuangan yang sangat tinggi baik materi maupun moril yang tiada ternilai demi keberhasilan penulis. Semoga Allah SWT 
memberikan kedudukan yang mulia di sisi-Nya.. Pada kesempatan ini pula, perkenankanlah penulis menyampaikan terima kasih yang tulus kepada:

1. Dr. Zainal Abidin Rahawarin, M.Si selaku Rektor IAIN Ambon, Dr. Mohdar Yanlua, MH selaku Wakil Rektor I, Dr. H. Ismail DP. M.Pd selaku Wakil Rektor II dan Dr. Abdullah Latuapo, M.Pd.I selaku Wakil Rektor III.

2. Dr. Samad Umarella, M.Pd selaku Dekan Fakultas IImu Tarbiyah dan Keguruan, Dr. Patma Sopamena, M.Pd. selaku Wakil Dekan I, Ummu Sa'idah, M.Pd.I selaku Wakil Dekan II, dan Dr. Ridhwan Latuapo, M.Pd.I selaku Wakil Dekan III.

3. Dr. Hj. Siti Jumaeda, M.Pd.I selaku Ketua Program Studi Pendidikan Agama Islam dan Saddam Husein, M.Pd.I selaku Sekretaris Program Studi Pendidikan Agama Islam, serta seluruh staf Program Studi Pendidikan Agama Islam.

4. Dr. Samad Umarella, M.Pd selaku Pembimbing I dan Saddam Husein, M.Pd.I selaku Pembimbing II yang telah meluangkan waktu membimbing penulis dengan penuh kesabaran dan keikhlasan sehingga penulis dapat menyelesaikan skripsi ini dengan baik.

5. Rivalna Riva'i, M.Hum selaku Pimpinan Perpustakaan IAIN Ambon beserta staf yang telah bersedia menyediakan literatur untuk penulis selama menyusun skripsi.

6. Dosen dan pegawai pada Fakultas IImu Tarbiyah dan Keguruan, khususnya Program Studi Pendidikan Agama Islam IAIN Ambon yang telah mendidik serta membimbing penulis hingga akhir studi.

7. Kepala SMA Negeri 5 Buru Kecamatan Lilialy Kabupaten Buru beserta seluruh guru dan siswa yang telah mengizinkan dan membantu penulis melakukan penelitian di sekolah tersebut.

8. Saudara-saudara tercinta yang telah dengan kerelaan hati membantu penulis baik dalam suka maupun duka, mereka pula yang telah 
menjadi sumber inspirasi penulis selama mengenyang pendidikan di Bumi Hijau IAIN Ambon.

\section{DAFTAR PUSTAKA}

[1] Arsyad, Azhar. Media Pembelajaran, Jakarta : RajaGrafindo Persada, 2006.

[2] Daryanto. Media Pembelajaran, Yogjakarta: Gava Media, 2003.

[3] Fatkhul Huda, Ahmad. Penerapan Media Pembelajaran Berbasis Multimedia LCD Proyektor Dalam Upaya Meningkatkan Motivasi Belajar IPA Siswa Kelas IV SD N I Taruman Tahun Ajaran 2013/2014.Naskah Publikasi. Fakultas Keguruan dan IImu Pendidikan, Universitas Muhammadiyah Surakarta, 2014.

[4] Gunawan, Heri. Kurikulum dan Pembelajaran Pendidikan Agama Islam, Bandung: PT. Alfabeta, 2012.

[5] Hamalik, Oemar. Kurikulum dan Pembelajaran, Cet. XII; Jakarta: Bumi Aksara, 2012.

[6] Margono, Metodologi Penelitian Pendidikan, Cet. VII; Jakarta : PT. Rineka Cipta, 2009.

[7] Rusmiyati, Ida Joko Nurkamto, dan Samsi Haryanto. Penggunaan Multimedia Dalam Pembelajaran Bahasa Sastra Indonesia Di SMP Negeri 2 Bawen Kabupaten Semarang. Jurnal Teknologi Pendidikan dan Pembelajaran. Vol.2, No.2, Edisi April 2014.

[8] Setyowati. 2007. Pengaruh Motivasi Belajar Terhadap Hasil Belajar Siswa Kelas VII SMPN 13 Semarang. Skripsi. Semarang : Fakultas Ekonomi Universitas Negeri Semarang. 